\title{
VEINS AND HYDROTHERMAL BRECCIAS OF THE RANDU KUNING PORPHYRY Cu-Au AND EPITHERMAL Au DEPOSITS AT SELOGIRI AREA, CENTRAL JAVA INDONESIA
}

\author{
Sutarto $^{* 1,2}$, Arifudin Idrus ${ }^{2}$, Agung Harijoko ${ }^{2}$, Lucas Donny Setijadji ${ }^{2}$, and Franz M. \\ Meyer ${ }^{3}$ \\ ${ }^{1}$ Universitas Pembangunan Nasional "Veteran" Yogyakarta \\ ${ }^{2}$ Department of Geological Engineering, Gadjah Mada University, Yogyakarta, Indonesia \\ ${ }^{3}$ RWTH Aachen University, Germany
}

\begin{abstract}
The Randu Kuning prospect is situated at Selogiri area, Wonogiri, Central Java, Indonesia. This location is about $40 \mathrm{~km}$ to the south-east from Solo city or approximately $70 \mathrm{~km}$ east of Yogyakarta city. Many Tertiary dioritic rocks related alterationmineralisation were found at the Randu Kuning area and its vicinity, including hornblende microdiorite, hornblende-pyroxene diorite and quartz diorite. Mineralisation type of the Randu Kuning prospect was interpreted as porphyry $\mathrm{Cu}-\mathrm{Au}$ and a number epithermal Au-base metals deposits in its surrounding. The closed existing of porphyry $\mathrm{Cu}-\mathrm{Au}$ and epithermal Au-base metals type deposits at the Randu Kuning area produced a very complex of veins and hydrothermal breccias crosscutting relationship. A lot of porphyry veins types were found and observed at the Randu Kuning area, and classified into at least seven types. Most of the porphyry veins were cross cut by epithermal type veins. Many epithermal veins also are found and crosscut into deeply porphyry vein types. There are genetically at least two type of hydrothermal breccias have recognized in the research area, i.e. magmatic-hydrothermal breccia and phreatomagmatic breccia. Magmatic hydrothermal breccias are mostly occured in contact be-
\end{abstract}

${ }^{*}$ Corresponding author: SUTARTO, Department of Geological Engineering, Gadjah Mada University. Jl. Grafika 2 Yogyakarta, Indonesia. E-mail: sutarto_geo@upnyk.ac.id tween hornblende microdiorite or quartz diorite and hornblende-pyroxene diorite, characterized by angular fragments/clasts supported or infilled by silicas, carbonates and sulphides matrix derived from hydrothermal fluids precipitation. Phreatomagmatic breccias are characterized by abundant of the juvenil clasts, indicated contact between hot magma with fluid or water as well as many wall rock fragments such as altered diorites and volcaniclastic rock clasts set in clastical matrix. The juvenil clasts usually compossed by volcanic glasses and aphanitic rocks in rounded-irregular shape. Both veining and brecciation processes have an important role in gold and copper mineralisation of the Randu Kuning Porphyry $\mathrm{Cu}-\mathrm{Au}$ and epithermal Au-base metals deposits, mostly related to the presence of quartz veins/veinlets containing significant sulphides, i.e., quartz with thin centre line sulphides (Abtype) veins, pyrite \pm chalcopyrite (C type) veinlets, pyrite $+q u a r t z \pm$ chalcopyrire \pm carbonate $(D$ type) veins of porphyry types as well as epithermal environment quarts+ sulphides+carbonate veins.

Keywords: Veins, Hydrothermal breccia, Porphyry, Epithermal

\section{Introduction}

The Randu Kuning porphyry $\mathrm{Cu}-\mathrm{Au}$ prospect area, situated in Selogiri, Wonogiri, Central Java, Indonesia. This location is reachable with 
four or two wheel vehicle, about $40 \mathrm{~km}$ to the south-east from Solo city, or approximately 70 $\mathrm{km}$ east of Yogyakarta (Figure 1).

The Randu Kuning area and its vicinity is a part of the East Java Southern Mountain Zone, mostly occupied by both plutonic and volcanic igneous rocks, volcanic clastic rocks, siliciclastic rocks as well as carbonate rocks. Magmatism and volcanism in this area is represented by the Mandalika Formation consisting mostly volcanic igneous rocks such as andesite-dacitic lavas, volcaniclastic rocks namely dacitic tuffs, and volcanic breccias. The rock unit was intruded by dioritic intrusive rocks. Volcaniclastic rocks of the Semilir Formation, as a product of the huge eruption, are exposed and scattered at the south of Selogiri area such as tuffs, lapilli tuffs, dacitic pumice breccias, tuffaceous sandstones and tuffaceous shales.

Many dioritic composition intrusive rocks were found at the Randu Kuning area, consist of pre, syn- and post-mineralization intrusive rocks. However, it is difficult to distinguish this kind of dioritic intrusive in the area, due to the similar composition and texture with varying relationship to alteration-mineralization. Imai et al. (2007) have identified three different type of intrusive rocks, namely hornblende andesite porphyry, hornblende diorite porphyry and hornblende diorite. Muthi et al. (2012) recognized that there are at least four type of diorite at the Randu Kuning area i.e. coarse grain diorite, medium diorite, microdiorite and porphyritic plagioclase diorite.

Mineralization type of Randu Kuning prospect was interpreted as a porphyry $\mathrm{Cu}-$ $\mathrm{Au}$ ore deposit and a number gold-base metals epithermal deposits in its surrounding (Imai et al., 2007; Suasta and Sinugroho, 2011; Corbett, 2011, 2012 and Muthi et al., 2012). The intensive erosion process has uncovered the upper parts of the porphyry deposit, whereas several gold-base metal epithermal are preserved along adjacent ridge (Suasta and Sinugroho, 2011). Many epithermal veins were also found and crosscut into deeply porphyry veins and related potassic alteration (Suasta and Sinugroho, 2011; Corbett, 2012).

Many researcher have recognized the miner- alization in the Selogiri area (Suprapto, 1998; Isnawan et al., 2002; Prihatmoko et al., 2002; Imai et al., 2007; Suasta and Sinugroho, 2011 and Muthi et al., 2012), but detailed scientific study on the deposit is still limited, particularly to develop the genetic model of hydrothermal deposit in the Selogiri area. The existing porphyry $\mathrm{Cu}-\mathrm{Au}$ and low sulphidation epithermal $\mathrm{Au}-$ base metals type deposits at the Randu Kuning area provide an excellent opportunity to study the evolution of the hydrothermal fluids from the deep porphyry system to the sallow low sulphidation epithermal setting, by integrating petrographic-ore microscopic, rock and mineral chemistry as well as fluid inclusion data.

Although researches on hydrothermal evolution of porphyry to epithermal mineralisation at several locations in the world have reported (e.g., Hedenquist et al., 1998; Muntean and Einaudi, 2001; Kouzmanov et al., 2009), but in Indonesia this theme has never been studied in detail by the integrating data approach mentioned above. Many breccias type including hydrothermal breccias type have recognized at the research area, but detailed study about it have not been done. Corbett $(2011,2012)$ has gave comment on the Randu Kuning porphyry $\mathrm{Cu}-$ $\mathrm{Au}$ project that there are many type of breccia at the Randu Kuning area as well as polyphasal brecciation have taken place both in porphyry and epithermal environment.

\section{Exploration history}

Explorations of copper and gold deposits in Wonogiri area have done since the Dutch era (1929-1935), and by reference of this exploration, then were followed by the Japanese during the occupation of Indonesia (1942-1954) (Isnawan et al., 2002). The production recorded from this mine is in small amounts and could be exported to Japan (Van Bemmelen, 1949). The remaining mine tunnel of Japanese, now can still be seen in the village Ngrejo, Tirtomoyo, Wonogiri (Prihatmoko et al., 2005).

After independence, in 1958, hiring the mine employs experts from Japan, the Indonesian government evaluated the existing hydrothermal ore deposits in Tirtomoyo, which stated 


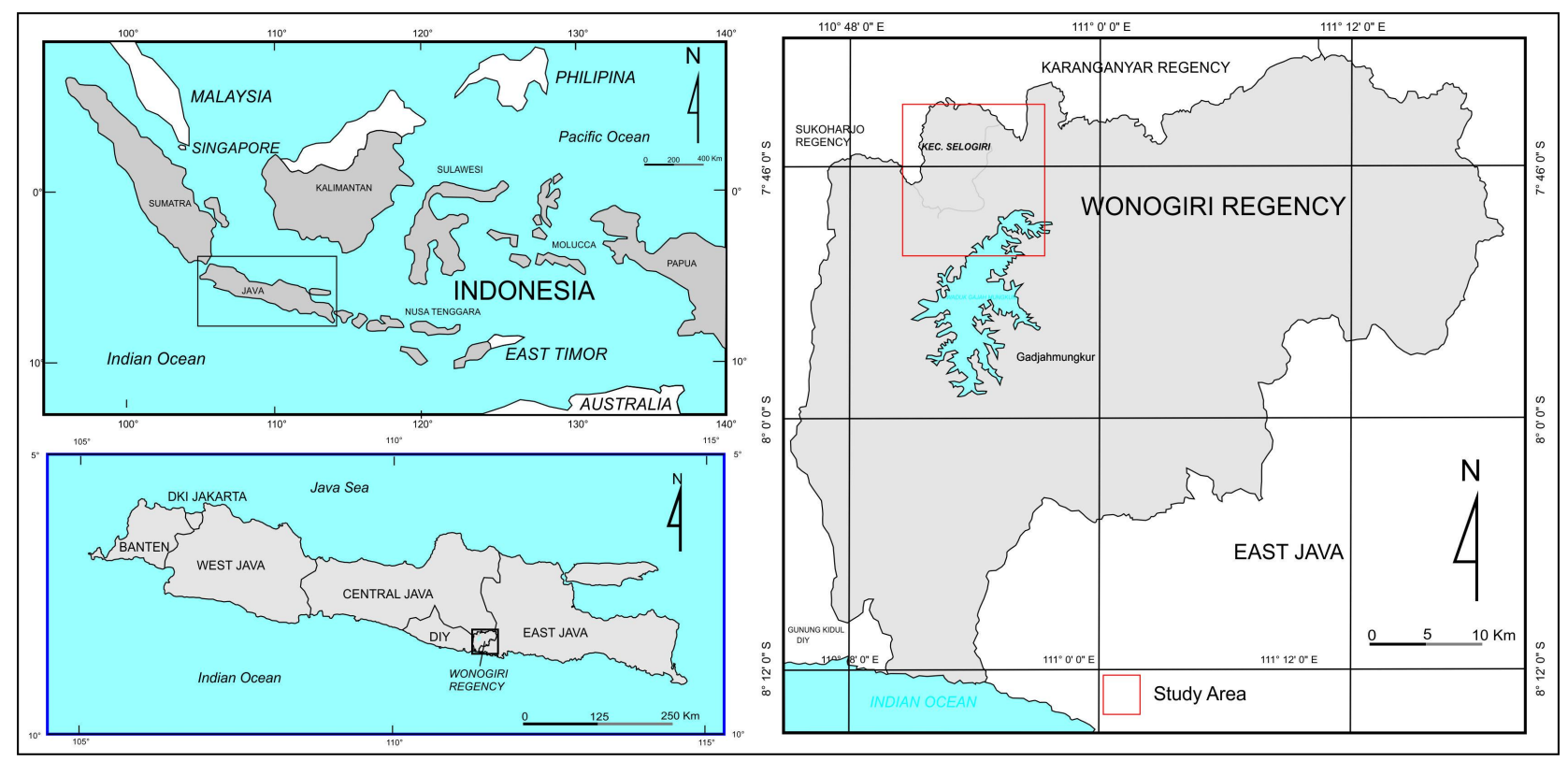

Figure 1: Location map of Selogiri area, Wonogiri.

that there were three abundant outcrops of quartz veins containing chalcopyrite (Isnawan et al., 2002). In 1969, PT. Kennecot started exploration through the COW Generation II, which covers an area of 7,000 $\mathrm{km}^{2}$ in Wonogiri, Pacitan, Ponorogo, and Trenggalek to seek the porphyry Cu deposits (Burton, 1971 in Prihatmoko et al., 2005). Since 1995, the Selogiri prospect area attracted the attention of university students when illegal gold mining activity started in the area (Suasta and Sinugroho, 2011).

May 2009, PT. Alexis Perdana Mineral (the owner of IUP in Selogiri) and PT. Oxindo Exploration subsidiary of the Minerals and Metals Group (MMG) signed a definitive Joint Venture Agreement to explore and develop the Selogiri porspect, and commenced the exploration activities (Suasta and Sinugroho, 2011). In 2011, Augur Resources then has 90\% register interest in PT. Alexis Perdana Mineral and the remaining $10 \%$ interest is held on behalf of PT. Oxindo.

\section{Materials and methods}

This paper is a preliminary study on the vein type and hydrothermal breccia and part of the dissertation research progress. In this study, veins and rocks samples were collected systematically from both drilling and local mining tunnel as well as surface outcrops. Secondary minerals assemblages were identified from polarizing light microscopic observation (120 samples), X-ray diffractometer (43 samples) and Qemscan analysis (4 samples). The X-ray diffractometer was conducted at the Geological Engineering Department of Gadjah Mada University using Rigaku RINT-2100. Petrographic and ore microscopic analysis were carried out at Geological Engineering Department of Gadjah Mada University and Department of Mineralogy and Economic Geology, RWTH Aachen University, Germany. Four selected samples representing potassic, inner propylitic and phyllic-argillic alteration types, were analysed at Department of Mineralogy and Economic Geology, RWTH Aachen University, Germany, using QemScan (Quantitative Evaluation of Minerals by Scanning Electron Microscopy).

\section{Geologic setting}

\section{Eastern Sunda arc}

Indonesia archipelagos are controlled by many magmatic arcs, vary in age from Late Mesozoic through the Cenozoic. Most mineralization are derived from five major Tertiary arcs 
include the Sunda-Banda, Central Kalimantan, Sulawesi-East Mindanau, Halmahera and Medial Irian Jaya (Carlile and Mitchell, 1994) (Figure 2).

Sunda-Banda arc is one of the most important six major Tertiary arcs in Indonesia extending from Sumatra through Java to east of Damar island, known has many ore deposits (van Leeuwen, 1994; Charlile and Mitchell, 1994). The arc is the longest arc in Indonesia, developed by northwards subduction of the Indian-Australian oceanic plate beneath the southeastern margin of Eurasian continental plate, named the Sundaland (Hamilton, 1979; Katili, 1989). Setijadji and Maryono (2012) divided this long arc in three segments, i.e., the Western Sunda arc (Sumatra island), the Eastern Sunda arc (Java, Bali, Lombok and Sumbawa or Flores islands), and the Banda arc for the islands east of Flores (Figure 3). The Eastern Sunda Arc is one of the most complex arc magmatism settings in the world (Setijadji and Maryono, 2012).

\section{Geology of the Selogiri and its vicinity}

Magmatism-volcanism products at Selogiri area indicated by the abundant of igneous rocks and volcanic clastic rocks of Mandalika and Semilir Formation as part of the Late Eocene-Early Miocene magmatism. A K/Ar age of the diorite porphyry within Mandalika Formation in the south flank of a wall of the depression is $21.7 \mathrm{Ma}$ (JICA-JOGMEG, 2004 in Imai et al. 2007). The eruption and deposition of the Semilir Formation is believed as the final stage of volcanic activity in the the Southern Mountains Arcs, which distributed as over a wide area and may be comparable to the Pleistocene eruption of Toba in Sumatra (Smyth et al., 2008). After the Semilir eruption, there was a lull in volcanic activity during the Middle Miocene (Smyth et al., 2008), and then followed by the movement in Late Miocene-Pliocene arc activity to the north of the Late Eocene-Early Miocene Southern Mountain Arc. There are many rocks types found at the Selogiri area and its surrounding, such as volcanic breccias, andesite lavas, tuffs, and many igneous intrusive rocks such as diorites and andesites of the Miocene Mandalika and Semilir Formations, unconformably underlie Quaternary volcanic rocks of Lawu and Merapi Volcanoes. Most of the Tertiary rocks have been strongly hydrothermal altered; causing primary rock forming minerals (feldspar, hornblende, pyroxene), were replaced by secondary minerals (chlorite, carbonate, quartz, hematite). Lithostratigraphically, these rocks could be grouped into many rock units, i.e.: tuff unit, andesitic lava, pumice breccia, calcareous sedimentary rock, dioritic intrusive rocks and hydrothermal breccias, volcanic breccia unit, and alluvial deposit, respectively from the oldest to the youngest (Figure 4). Based on the observation both on surface outcrops and drilling core samples, the intrusive rocks at the researched area consist of hornblende-pyroxene diorite (previous researcher called as a medium diorite), hornblende microdiorite and quartz diorite.

\section{Geology of the Randu Kuning area}

\section{Lithology}

Randu Kuning area is situated in the area where porphyry $\mathrm{Cu}-\mathrm{Au}$ and epithermal $\mathrm{Au}$ low sulphidation occured. The area is occupied by dioritic intrusive rocks and hydrothermal breccias as well as many veins/veinlets types. Intrusive rocks consist of hornblende-pyroxene diorite, hornblende microdiorite and quartz diorite, while the hydrothermal breccia can be classified as magmatic hydrothermal breccia and phreatomagmatic breccia.

Hornblende-pyroxene diorite generally shows gray color in fresh condition (lighter than hornblende microdiorite), porphyritic texture (moderate-strong), having medium crystal size $(1-2 \mathrm{~mm})$ with pyroxene and hornblende phenocryst size varies up to $2 \mathrm{~cm}$. Contain high proportion of plagioclase or at about 3550 percent with lesser amount of hornblende and pyroxene (3-8 percent). At the contact with the microdiorite, most of the primary minerals generally altered to the secondary minerals formed potassic zones and gradually became into propylitic zone outward.

Hornblende microdiorite is characterized by fine grained phenocrysts size $(<1 \mathrm{~mm})$, many 


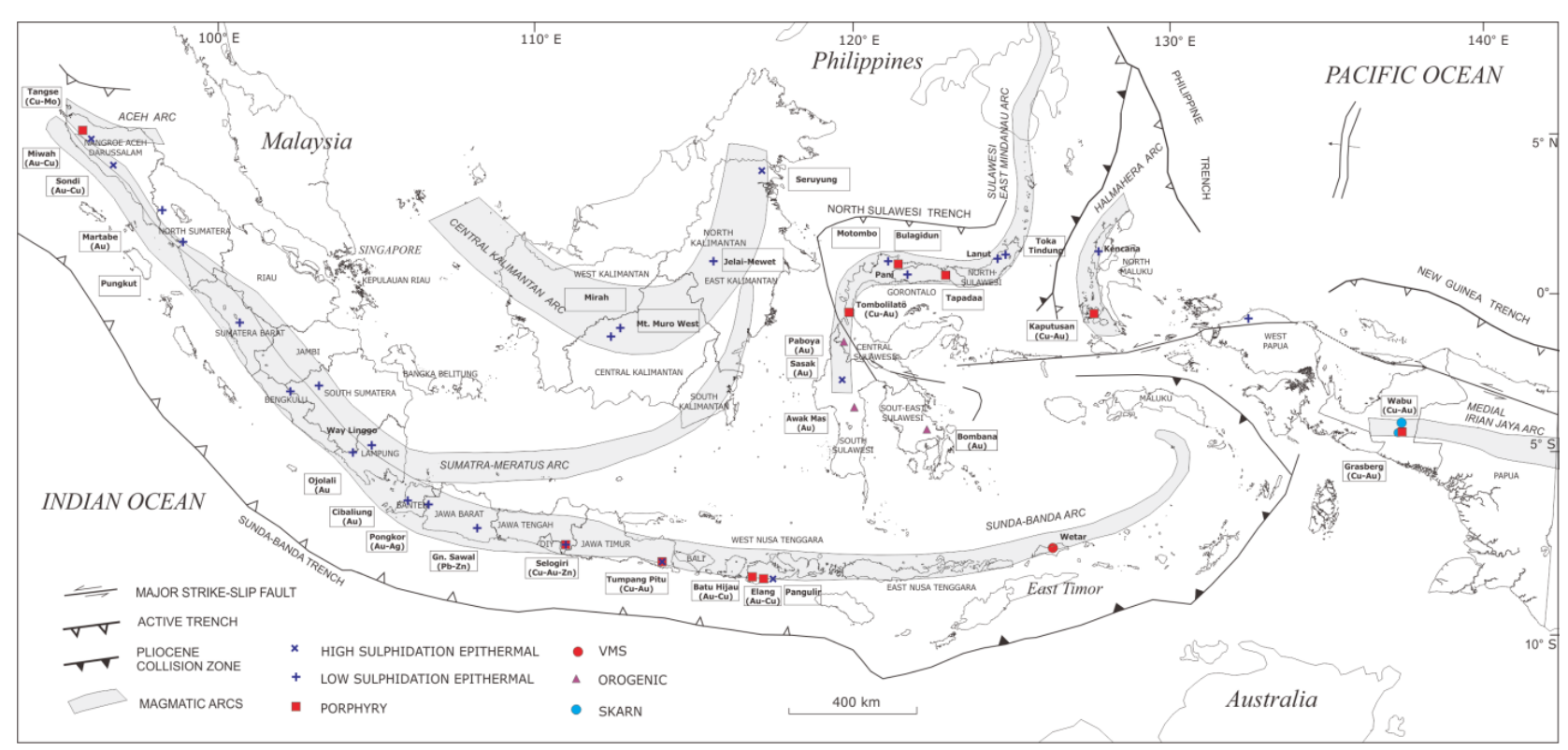

Figure 2: Magmatic arcs distributing in Indonesia (redraw after Carlile and Mitchell, 1994 and different styles of mineral deposits in Indonesia (Carlile and Mitchell, 1994; Setijadji and Maryono, 2012).

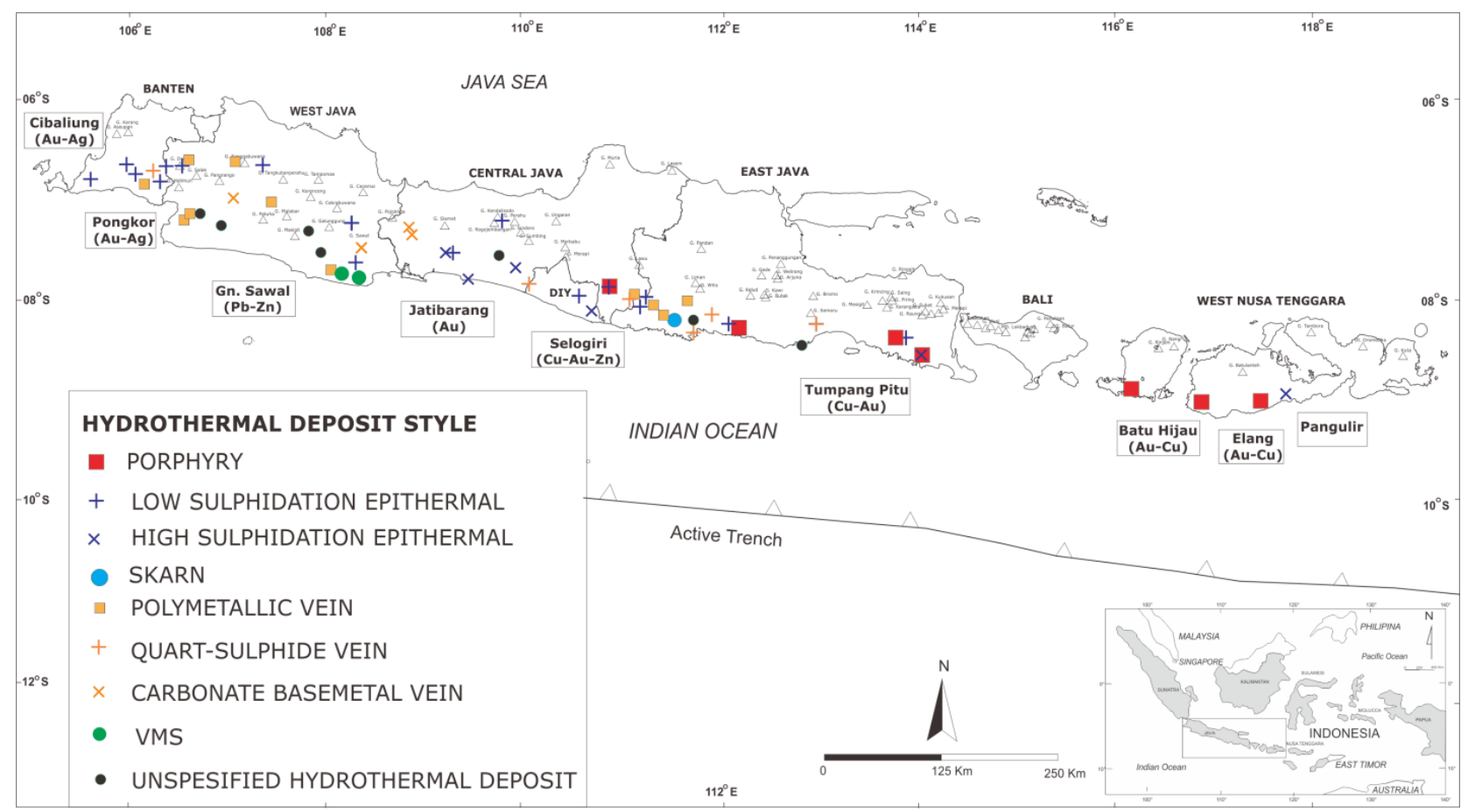

Figure 3: The different styles of mineral deposit distribution in the Eastern Sunda Arc (Modified from Setijadji et al., 2006; Setijadji and Maryono, 2012). 


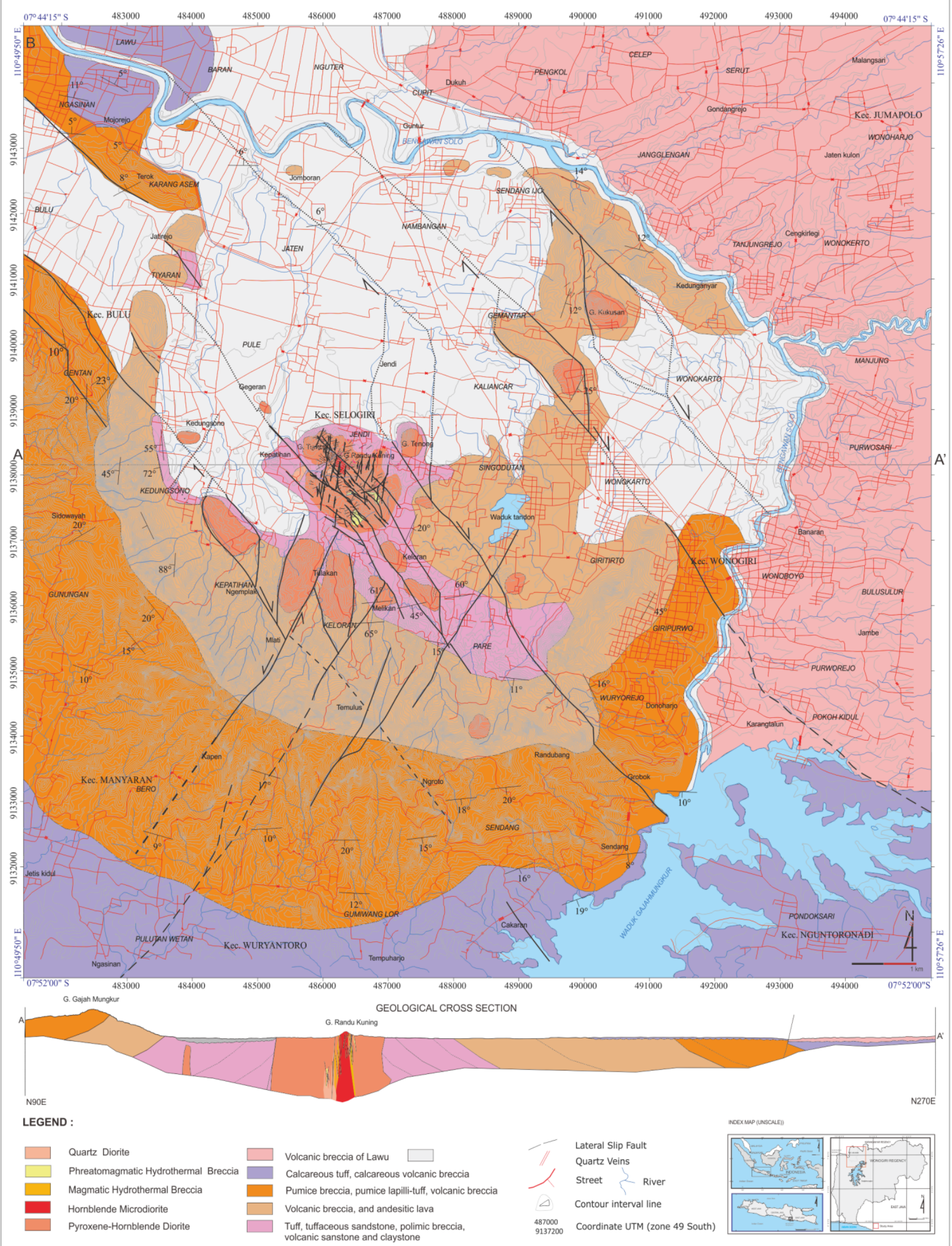

Figure 4: Geological map of the Selogiri area and its vicinity. 
of samples microscopically classified as andesite (porphyritic texture), commonly consist of about 30-45 percent of plagioclase and 5-14 percent of hornblende. The hornblende microdiorite is believed to be responsible for the extensive alteration and $\mathrm{Cu}-\mathrm{Au}$ porphyry ore deposit in the study area. Physically, it seen darker in color and finer in crystals size than pyroxene diorite. It is caused not only the amount of mafic minerals but also the abundant of the secondary magnetite. Most of the body was altered to potassic assemblage and lack of propylitic and phyllic alteration types.

Quartz diorite intrusive rock has the brightest colors and the coarsest crystals sizes $(>2$ $\mathrm{mm})$, equigranular to weak porphyritic texture, characterized by the abundant of plagioclases $(40-55 \%)$ and small quantities of quartz (4-7\%) and alkali feldspars (2-5\%). Due to have coarse grained crystal size, Muthi et al. (2012) recognized and described the intrusive as a coarse diorite. It was generally altered to phyllicargillic and propylitic minerals assemblage, associated with Au-base metals epithermal type mineralization. Dimensions and distribution of this intrusion relatively narrower and smaller than those of hornblende-pyroxene diorite and hornblende microdiorite intrusions.

\section{Structural Geology}

Major structures at the Selogiri area are dominated by relatively the NW-SE, NE-SW, and rare $\mathrm{N}-\mathrm{S}$ trends, cross cut all of the rocks in the area, but minor E-W trending fault also was found (Suasta and Sinogrogo, 2011). The earliest and most dominant structures in the research area is the NW-SE dextral (right) lateralslip fault, and commonly have a longer dimension rather than the other trends. These structural trends then were cross cut by NE-SW and N-S sinistral (left) lateral-slip faults. The NESW and N-S trend mostly concentrated in the central area.

Drill core and surface outcrop data suggest the the earlier porphyry vein types were may be controlled by dextral (right) lateral-slip faults, whereas the later porphyry vein and epithermal vein types controlled by sinistral (left) lateral- slip faults. The geological map of the Randu Kuning area can be seen at Figure 5

\section{Alteration and Mineralization}

Creasey (1966) suggested the classification of hydrothermal alteration type on porphyry copper deposit into three types, i.e., prophylitic (chlorite+calcite \pm epidote \pm talc), argillic (kaolinite or dickite)+ montmorillonite \pm sericite \pm chlorite, potassic (Kfeldspar+biotite \pm magnetite \pm quartz \pm chlorite), and quartz+sericite+pyrite mineral assemblages. Lowell and Guilbert (1970) created a model of alteration-mineralization on porphyry ore deposits as well, adding the term of phyllic type, for quartz+sericite+pyrite \pm chlorite \pm rutil \pm chalcopyrite mineral assemblage. Due to many new prospects of hydrothermal ore mineralization around the world were found, then proposed many new term alteration type such as advanced argillic, intermediate argillic and inner propylitic (Seedorff et al., 2005; Sillitoe, 2010). Alteration zones distribution of the researched area are generally controlled by the NE-SW and NW-SE trending structure. At least eight types of hydrothermal alteration at the Randu Kuning area and its vicinity had identified (Figure 6):

1. Magnetite+biotite \pm K-feldspar \pm chlorite (potassic).

2. Chlorite + sericite + magnetite \pm actinolite.

3. Chlorite+magnetite \pm actinolite \pm carbonate (inner propylitic).

4. Chlorite+epidote \pm carbonate (outer propylitic)

5. Sericite+quartz+pyrite (phyllic).

6. Illite + kaolinite \pm smectite (intermediate argillic).

7. Illite + kaolinite \pm pyrophyllite \pm alunite (advanced argillic).

8. Quartz+chlorite (silicic) zones.

The magnetite+biotite \pm K-feldspar \pm chlorite (potassic) zone scattered on microdiorite intrusive rocks body and small part of pyroxene diorite intrusive rocks especially in contact to the microdiorite intrusion of Randu Kuning 


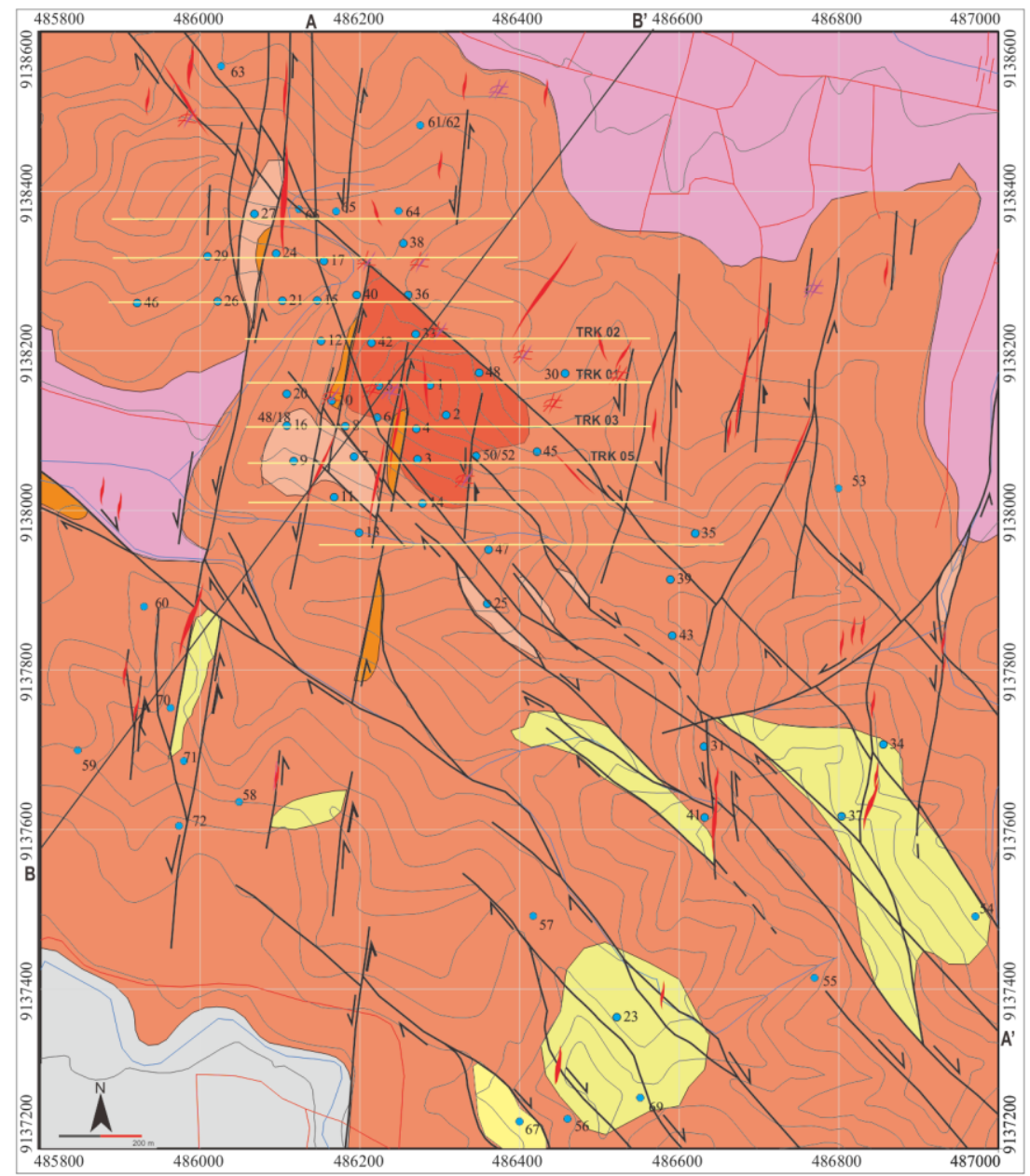

\section{GEOLOGICAL MAP OF THE RANDU KUNING}

LEGEND :

\section{Alluvial Deposit}

Tuff, tuffaceous sandstone

Quartz Diorite

Phreatomagmatic Hydrothermal Breccia

Magmatic Hydrothermal Breccia

Hornblende Microdiorite

Pyroxene-Hornblende Diorite

Righ Lateral Slip Fault Left Lateral Slip Fault Quartz Vein \# Quartz Stockwork Street 2 River

Contour interval line

Bore Hole

Geological Cross Section Line

487000

Coordinate UTM (zone 49 South)
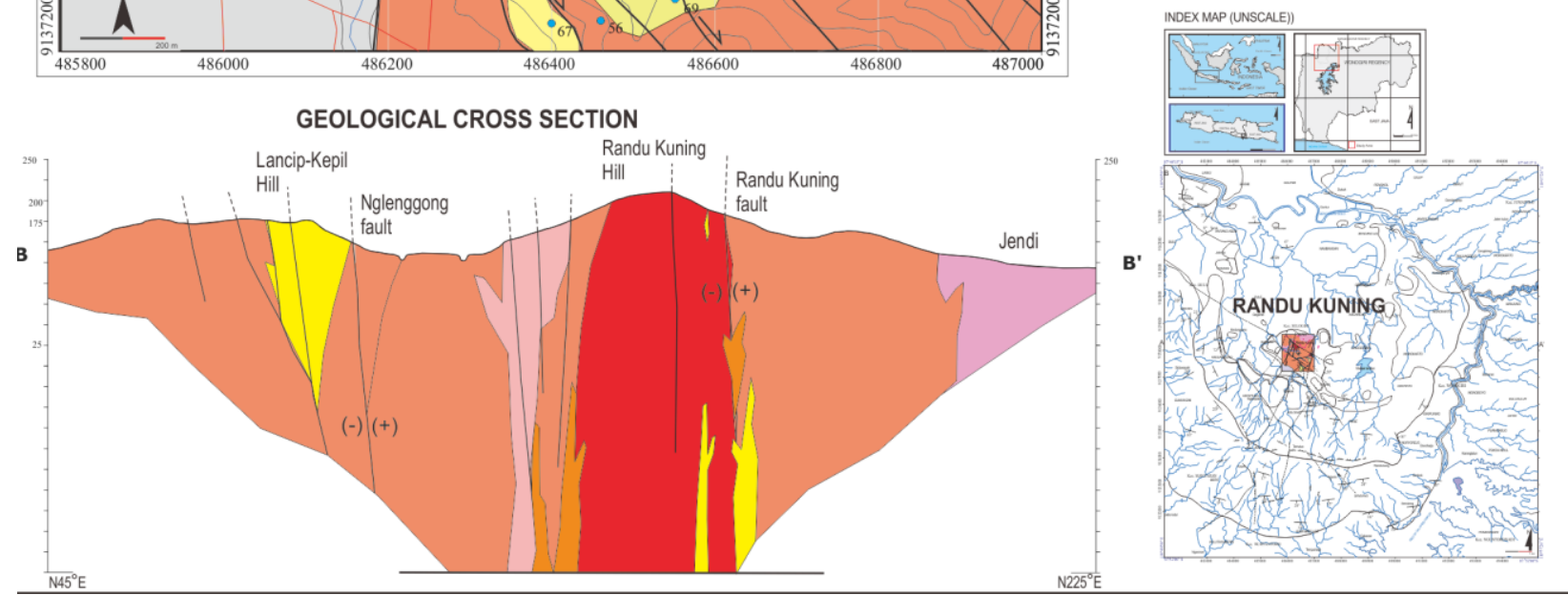

Figure 5: Geological map of Randu Kuning area and its vicinity. 


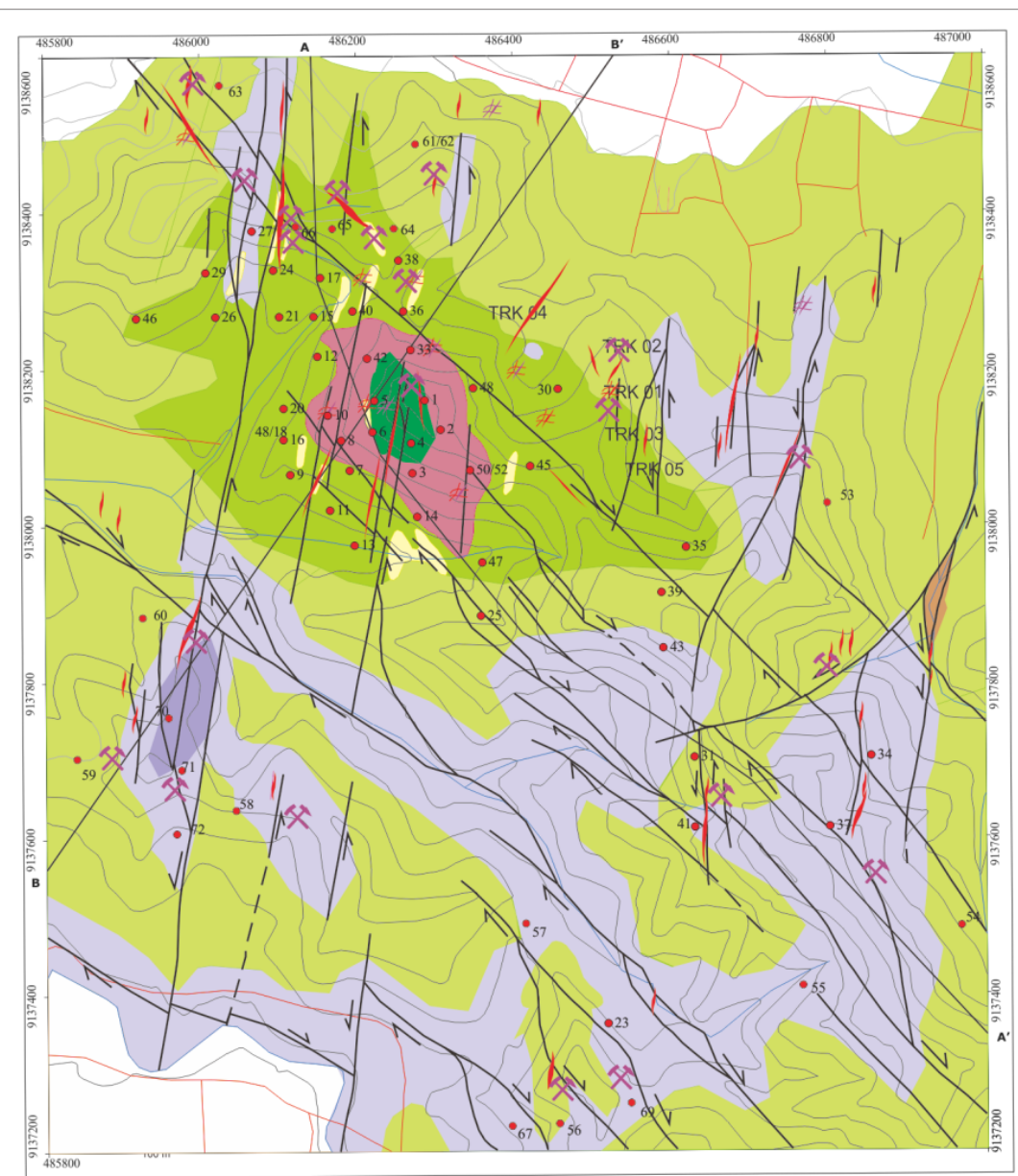

ALTERATION ZONE CROSS SECTION

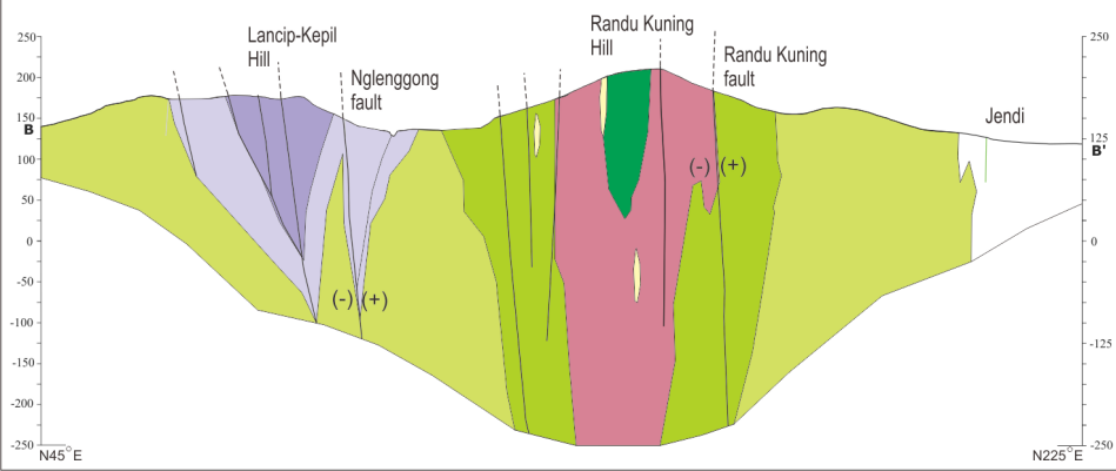

ALTERATION ZONE MAP OF THE RANDU KUNING AREA $\hat{\Lambda}^{N}$

Magnetite+biotite-K Feldspar \pm chlorite (potassic) zone

Chlorite+sericite+magnetit \pm actinolite zone

Chlorite+magnetit \pm actinolite \pm carbonate (Inner Prophyllitic) zone

Chlorite+quartz \pm epidote \pm carbonate (Outer Prophyllitic) zone

Sericite+quartz+pyrite \pm kaolinite \pm smectite (Phyllic) zone

Illite + Kaolinite + quartz \pm smectite (Intermediet Argillic) zone

Illite+quartz+kaolinite \pm pyrophyllite \pm Alunite (Advanced Argillic) zone

quartz+chlorite (Silisic zone)

\section{Unalterated}

\section{Righ Lateral Slip Fault} Left Lateral Slip Fault Quartz Vein Zone

\# Quartz Stockwork

X Local Mining

Street $\sim$ River

$\triangle \quad$ Contour interval line

- 12 Bore Hole

TRK 01 Geological Cross

487000
9137200

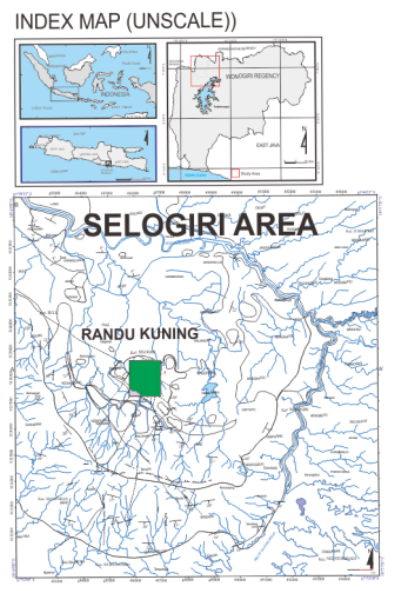

Figure 6: Alteration zone map of Randu Kuning area and its vicinity. 
hill. This zone is characterized by the present of secondary minerals assemblage i.e. one or both of secondary biotite and/or K-feldspar associated with magnetite, actinolite, quartz and lack of carbonate minerals (Suasta and Sinugroho, 2011; Corbett, 2011, 2012 and Muthi et al., 2012).

The chlorite+sericite+magnetite \pm actinolite is widespread on the upper part of the magnetite+biotite \pm K-feldspar \pm chlorite (potassic) characterizing by the dominant of chlorite and sericite, although other secondary minerals such as magnetite, quartz, and sometimes actinolite are still found. The chlorite+sericite+magnetite \pm actinolite zone is developed on the small upper part of hornblende microdiorite. The chlorite + magnetite + \pm actinolite \pm carbonate alteration type is commonly recognized between magnetite + biotite \pm K-feldspar \pm chlorite (potassic) zone and chlorite+epidote \pm carbonate (outer propylitic) zone. The zone mostly is widespread in pyroxene-hornblende diorite rocks, and within small part of hornblende microdiorite. In some places this alteration zones seen cut to minerals assemblage of the magnetite + biotite \pm K-feldspar \pm chlorite (potassic) zone and gradually outward changed to chlorite+epidote \pm carbonate (outer propylitic) zone. The chlorite+epidote \pm carbonate, (outer propylitic) alteration zone is widespread on pyroxene-hornblende diorite rocks and small part of quartz diorite, gradually from the inner propylitic to least altered rock, comprising of chlorites, epidotes, carbonates and quartz.

The sericite+quartz+pyrite (phyllic) alteration is commonly appear in the fault structure zones, locally overprint to the potassic alteration and inner propylitic zone, on hornblende-pyroxene diorite rocks, microdiorite hornblende as well as quartz diorite (Suasta and Sinugroho, 2011; Corbett, 2011, 2012 and Muthi et al., 2012). This zone is characterized by retrograde silica-sericite-chlorite-pyrite assemblages, which is mostly limited to fault zones or selvages to late stage quartz-pyrite veins likened to D veins (Corbett, 2012).

The illite+kaolinite \pm smectite, (intermediate argillic) zone appears mainly adjacent to breccia and fault zone, especially in the epither- mal prospect area, which is characterized by the present of clay minerals. Illite, kaolinite and smectite are the main minerals identified in the vein samples suggesting structural controlled argillic alteration (Muthi et al., 2012). The illite + kaolinite \pm pyrophyllite \pm alunite (advanced argillic) is situated at the centre of Kepil hill, southwest of the Randu Kuning hill, comprising mostly illite, pyrophyllite, kaolinite, quartz and lack of alunite, carbonate and chlorite. The quatz+chlorite (sillisic) zone is restricted found at the fault zones, both within drilling core data and surface outcrop, consist of quartz, sericite, carbonate, clay minerals and opaque minerals. It is mostly related to the preatomagmatic hydrothernal breccia occurrence of the epithermal system.

\section{Veins and hydrothermal breccias}

\section{Veins types}

An understanding of the veins and veinlets in the porphyry system is very important, especially in the $\mathrm{Cu}$-Au porphyry deposit, as most of mineralization is associated with the presence of veins and veinlets. Various types of veins in porphyry-type ore deposit are summarized from several experts (Gustafson and Hunt, 1975; Corbett, 2008; Sillitoe, 2010; Corbett, 2012) include EB type or EDM type, M type, A type, $B$ type, $A B$ type, $C$ type and $D$ type. A lot of vein types were observed at the Randu Kuning area, both porphyry vein and epithermal vein types. Some of them are difficult to be grouped according to the classification of previous researchers above. Here are some vein types criteria that were found in the study area based on observations of drilling core samples and surface outcrops (using compilation of Gustafson and Hunt, 1975; Corbett, 2008; Sillitoe, 2010; Corbett, 2012). At least seven porphyry veins type have been observed, respectively from the earliest are (Figure 7):

1. Magnetite-chalcopyrite \pm quartz-biotite,

2. Quartz \pm magnetite (A type),

3. Banded/Laminated quartz-magnetite (M type),

4. Quartz $\pm K-f e l d s p a r(B$ type), 
5. Quartz with thin centre line sulphide (AB type),

6. Pyrite \pm chalcopyrite (C type), and

7. Pyrite-quartz+chalcopyrire+carbonate type).

Most of the porphyry vein style cross cut by epithermal vein types (Figure 8). At least six epithermal environment veins classifying into two group that are sulphide \pm quat \pm calcite \pm magnetite veins and quartz + calcite \pm gypsum \pm sulphide veins.

\section{Hydrothermal breccia}

Many experts have tried to classified breccia both on the basis of genetic and descriptive, such as Sillitoe (1985), Baker et al. (1986), Lawless and White (1990). Sillitoe (1985) classified ore-related hydrothermal breccia into magmatic hydrothermal breccia, hydromagmatic breccia (phreatic and phreatomagmatic), magmatic breccia, intrusive breccia and tectonic breccia.

The hydrothermal breccia in the Randu Kuning and its vicinity has not previously been reported in detail. Corbett (2011) stated that the upper portion of breccia pipe of Jangglengan (WDD23) is intersects milled matrix breccia typical of other Pacific rim phreatomagmatic breccia pipes where are intruded by breccias term milled clast intrusion matrix breccias of an interpreted magmatic hydrothemal origin.

In the basis of Sillitoe (1985) classification, genetically many type of breccias have recognized in the researched area, such as hydrothermal breccias, volcanic breccias, fault breccia and intrusive breccia. In this paper we focus to discuss about hydrothermal breccia only. There are at least two type of hydrothermal breccia have recognized in the research, i.e. magmatichydrothermal breccias and phreatomagmatic breccias, which were found at the Randu Kuning hill area (Table 2. Magmatic-hydrothermal breccias are products of the release of hydrothermal fluids from magma chamber (Sillitoe, 1985). As an intrusive body cools, the residual melt become increasingly concentrated in volatile components including water and it therefore has a considerable potential for hydraulic fracturing of overlying rocks forming breccia and related mineral deposits (Lawless and White, 1986). Phreatomagmatic breccia occurred when upwelling magma encounter water, may be groundwater, connate water or a body or surface water (Lawless and White, 1986).

\section{Magmatic hydrothermal breccia}

Magmatic-hydrothermal breccias in research area are characterized by various irregular body, showing subvertical to vertical in contact to the wall rocks, fragments mostly monomic, i.e. various altered diorite, angular-subrounded and larger in grain size $(0.5-8.4 \mathrm{~cm})$, matrix mostly consist of hydrothermal minerals (magnetite, chalcopyrite and pyrite) as open space infilling, fragment/matrix ratio is high (60-90 vol. \%) or predominantly fragment supported, texture/structures usually cracked, jig-saw and rotated fragments, no fluidization. The breccias are associated with potassic, phyllic and propylitic alteration type and open space infilling mineralization as well as veins/veinlets overprinting (Table 2; Figure 9). This breccias have a different characteristics to those of phreatomagmatic breccias, particularly in fragment and matrix as well as mineralization style. Magnetite-K-feldspar-biotite (potassic) altered diorite clasts and also later magnetite flooding in the matrix indicated that the breccias developed during the process of intrusion emplacement and hydrothermal alteration (Corbett, 2012).

\section{Phreatomagmatic breccia}

Phreatomagmatic breccias exhibite, irregular dyke and pipe body, subvetical-vertical, fragments/clasts consist of polymic components including juvenil (mostly rounded) and various wall rock such as altered diorites, veins/veinlets, sandstone, quartzite, conglomerate and schist (mostly subangular), $0.2-4.5 \mathrm{~cm}$ in size, low fragment/matrix ratio (10-65 vol. $\%)$. These breccia commonly show fluidization, associated with potassic, propylitic and argillic alteration type, mineralization occurred in both 

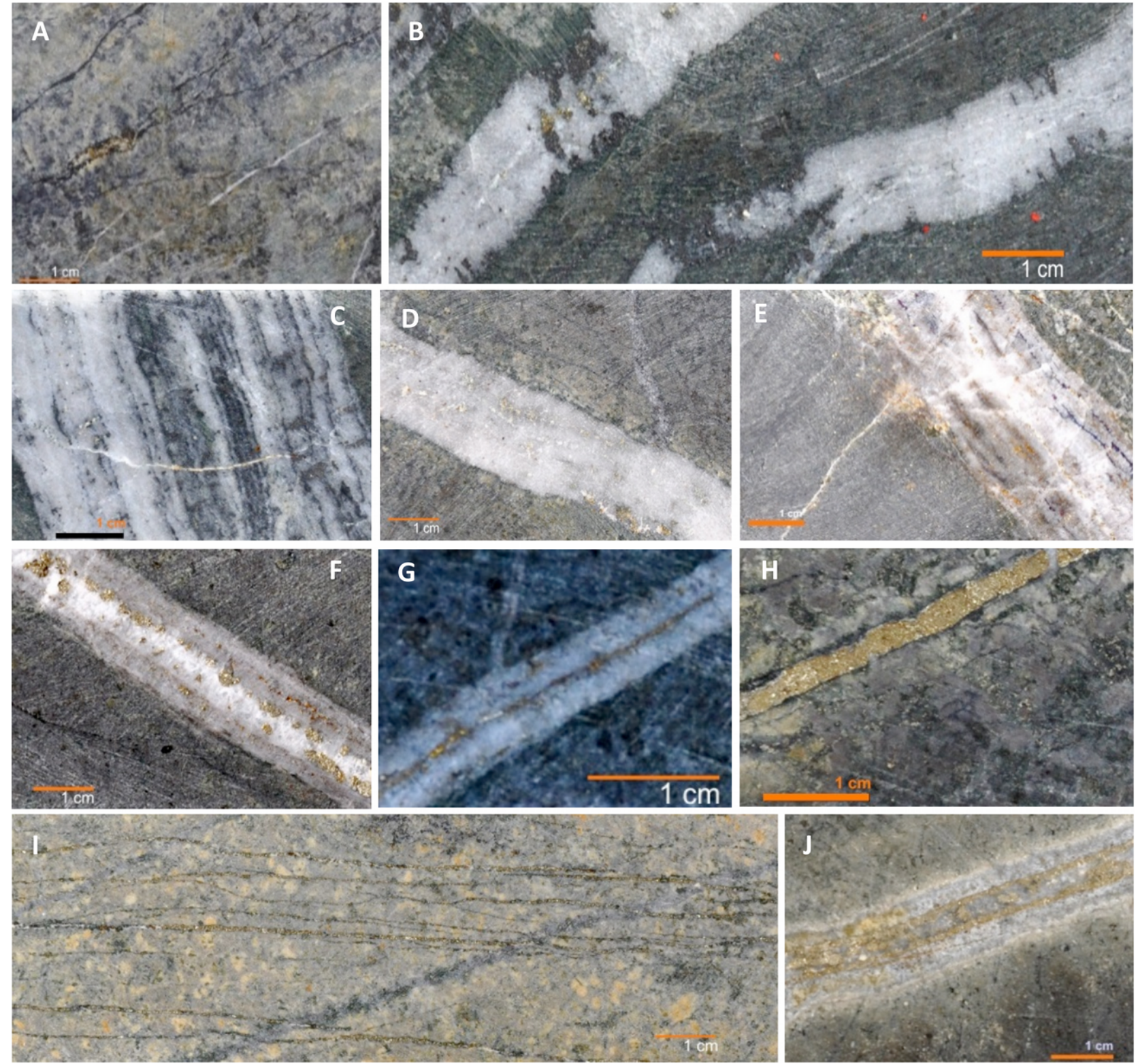

Figure 7: Many porphyry vein types at the Randu Kuning area. A) Magnetite-biotite-chlorite chalcopyrite veinlets as the earliest vein/veinlets (WDD 02-49.80); B) Quartz-magnetite vein with lesser disseminated chalcopyrite-pyrite (A vein) (WDD19-117.80); C) Laminated quartz-magnetite M type (WDD48-252.85); D) Quartz vein (WDD48-169.55); E) Sheeted quartz-sulphides (chalcopyrite, bornite-pyrite) (AB)(WDD05-61.50); F) Comb structure quart-sulphide vein, infilled by later stage of carbonate in the centre line (WDD-128.40); G) Quartz AB vein with central line thin pyrite-chalcopyrite (WDD07-69.60); H) Pyrite-chalcopyrite (C type) vein with sericite-chlorite halos (WDD48-281.65); I) magnetite-chlorite veinlet cut by paralel pyrite-chalcopyrite veinlets (C vein) (WDD18-81.90); M) Crustiform quartz-chalcopyrite-pyrite-carbonate (D type) vein (WDD45335.50). 
SUTARTO et al.

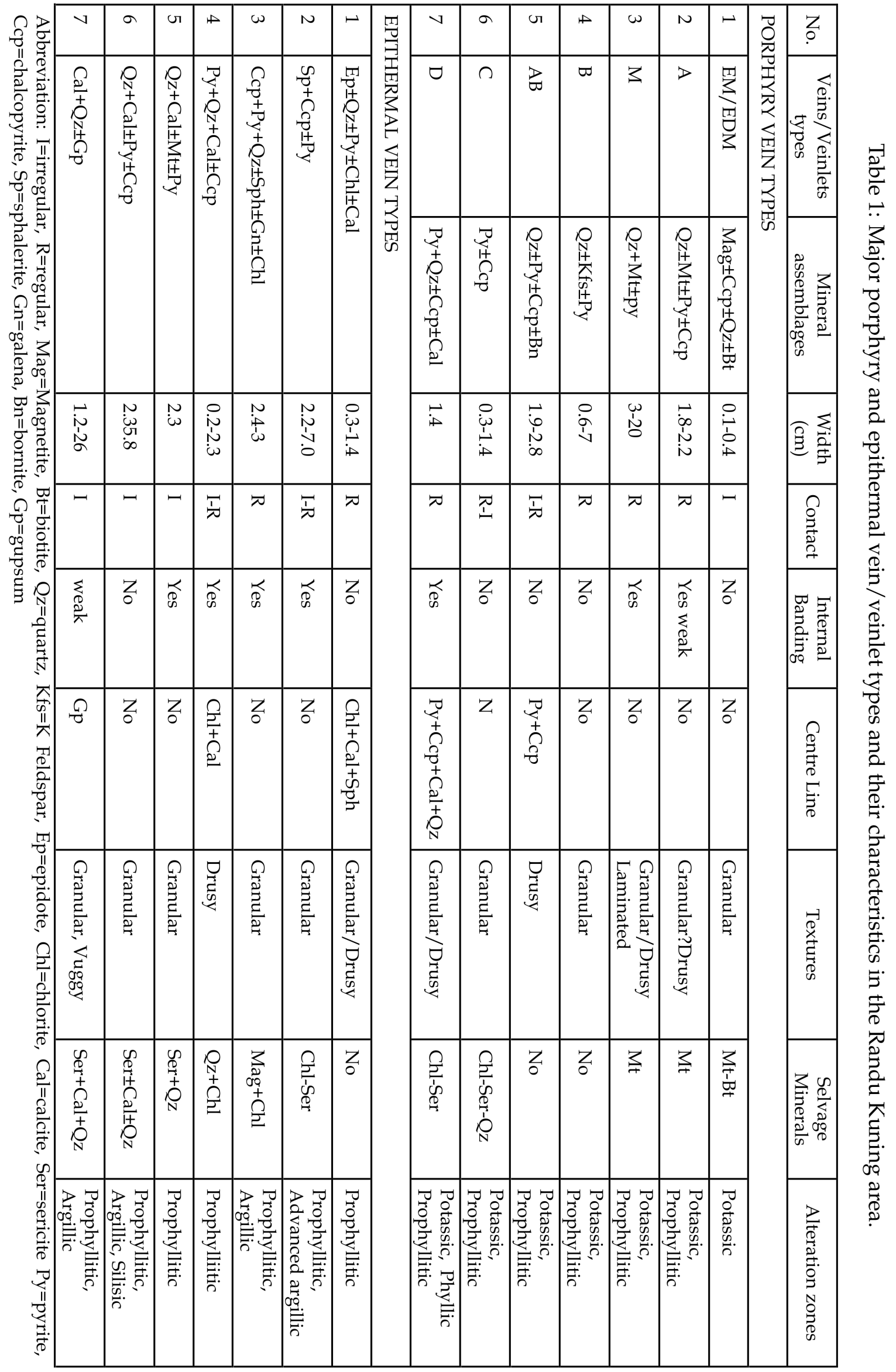


Table 2: Characteristics of the hydrothermal breccia at the Randu Kuning area and its vicinity.

\begin{tabular}{|c|c|c|c|c|}
\hline & $\begin{array}{l}\text { Magmatic } \\
\text { Hydrothermal }\end{array}$ & $\begin{array}{l}\text { Phreatomagmatic } \\
\text { (Porphyry level) }\end{array}$ & $\begin{array}{l}\text { Phreatomagmatic } \\
\text { (Epithermal level) }\end{array}$ \\
\hline \multicolumn{2}{|c|}{$\begin{array}{l}\text { Geometry of breccia } \\
\text { body }\end{array}$} & $\begin{array}{l}\text { Various irregular } \\
\text { body }\end{array}$ & irregular dyke & $\begin{array}{l}\text { pipe body?, irregular } \\
\text { dyke }\end{array}$ \\
\hline \multicolumn{2}{|c|}{$\begin{array}{l}\text { Contact to the wall } \\
\text { rock }\end{array}$} & $\begin{array}{l}\text { Subvertical to } \\
\text { vertical }\end{array}$ & $\begin{array}{l}\text { Subvertical to } \\
\text { vertical }\end{array}$ & Subvertical to vertical \\
\hline \multirow[t]{3}{*}{$\begin{array}{l}\text { Fragmen } \\
\text { t/Clast }\end{array}$} & $\begin{array}{l}\text { Compositio } \\
\mathrm{n}\end{array}$ & $\begin{array}{l}\text { Monomic: various } \\
\text { altered diorite }\end{array}$ & $\begin{array}{l}\text { Polimics: Juvenil- } \\
\text { wall rock } \\
\text { fragments ( various } \\
\text { altered diorite, } \\
\text { veins, sandstone, } \\
\text { quartzite, } \\
\text { conglomerate, } \\
\text { schist) }\end{array}$ & $\begin{array}{l}\text { Polimics: Juvenil-wall } \\
\text { rock fragments ( } \\
\text { various altered diorite, } \\
\text { veins, sandstone, } \\
\text { quartzite, } \\
\text { conglomerate, schist) }\end{array}$ \\
\hline & Size & $0,5-8.4 \mathrm{~cm}$ & $0.2-4.0 \mathrm{~cm}$ & $0.2-4.5 \mathrm{~cm}$ \\
\hline & Rounding & $\begin{array}{l}\text { Angular- } \\
\text { subrounded }\end{array}$ & $\begin{array}{l}\text { Rounded } \\
\text { (particularly } \\
\text { juvenil fragments) } \\
\text { to subangular (wall } \\
\text { rock fragments) } \\
\end{array}$ & $\begin{array}{l}\text { Rounded (particularly } \\
\text { juvenil fragments) to } \\
\text { subangular (wall rock } \\
\text { fragments) }\end{array}$ \\
\hline \multicolumn{2}{|l|}{ Matrix } & $\begin{array}{l}\text { Mostly } \\
\text { hydrothermal } \\
\text { minerals as open } \\
\text { space infilling } \\
\text { (magnetite, } \\
\text { chalcopyrite, } \\
\text { pyrite) as well as } \\
\text { sand sized clatic } \\
\text { grains }\end{array}$ & $\begin{array}{l}\text { Sand-granule sized } \\
\text { clastic grains, } \\
\text { rarely } \\
\text { hydrothermal } \\
\text { minerals as open } \\
\text { space infilling } \\
\text { (magnetite,chlorite, } \\
\text { chalcopyrite) }\end{array}$ & $\begin{array}{l}\text { Sand-granule sized } \\
\text { clastic grains, rarely } \\
\text { hydrothermal minerals } \\
\text { as open space infilling } \\
\text { (sphalerite, } \\
\text { pyrite,epidote } \\
\text { carbonate) }\end{array}$ \\
\hline \multicolumn{2}{|c|}{ Fragment/matrix ratio } & $\begin{array}{l}60-90 \mathrm{vol} \% \\
\text { fragments, } \\
\text { predominantly } \\
\text { fragments } \\
\text { supported } \\
\end{array}$ & $\begin{array}{l}10-65 \text { vol \% } \\
\text { fragments, matrix } \\
\text { supported }\end{array}$ & $\begin{array}{l}10-65 \text { vol \% fragments, } \\
\text { matrix supported }\end{array}$ \\
\hline \multicolumn{2}{|c|}{ Textures/structures } & $\begin{array}{l}\text { Milled intrusion } \\
\text { clast matrix, } \\
\text { crackel, jig-saw }\end{array}$ & Milled matrix & $\begin{array}{l}\text { Milled matrix, } \\
\text { bedded,graded } \\
\text { bedding, rebrecciated } \\
\text { clasts, cut by } \\
\text { microbreccia dyke and } \\
\text { carbonate-sphaerite- } \\
\text { pyrite vein/veinlets }\end{array}$ \\
\hline \multicolumn{2}{|c|}{ Fluidization } & no & yes & yes \\
\hline \multicolumn{2}{|c|}{ Alteration } & $\begin{array}{l}\text { Potassic, phyllic, } \\
\text { prophyllitic }\end{array}$ & $\begin{array}{l}\text { potassic, } \\
\text { prophyllitic }\end{array}$ & Argillic, prophyllitic \\
\hline \multicolumn{2}{|c|}{ Mineralisation } & $\begin{array}{l}\text { open space } \\
\text { infilling, } \\
\text { overprintting veins }\end{array}$ & $\begin{array}{l}\text { Dessimination } \\
\text { within both } \\
\text { fragments and } \\
\text { matric, open space } \\
\text { infilling, } \\
\text { overprinting veins }\end{array}$ & $\begin{array}{l}\text { Dessimination within } \\
\text { both fragments and } \\
\text { matric, open space } \\
\text { infilling, overprinting } \\
\text { veins }\end{array}$ \\
\hline
\end{tabular}



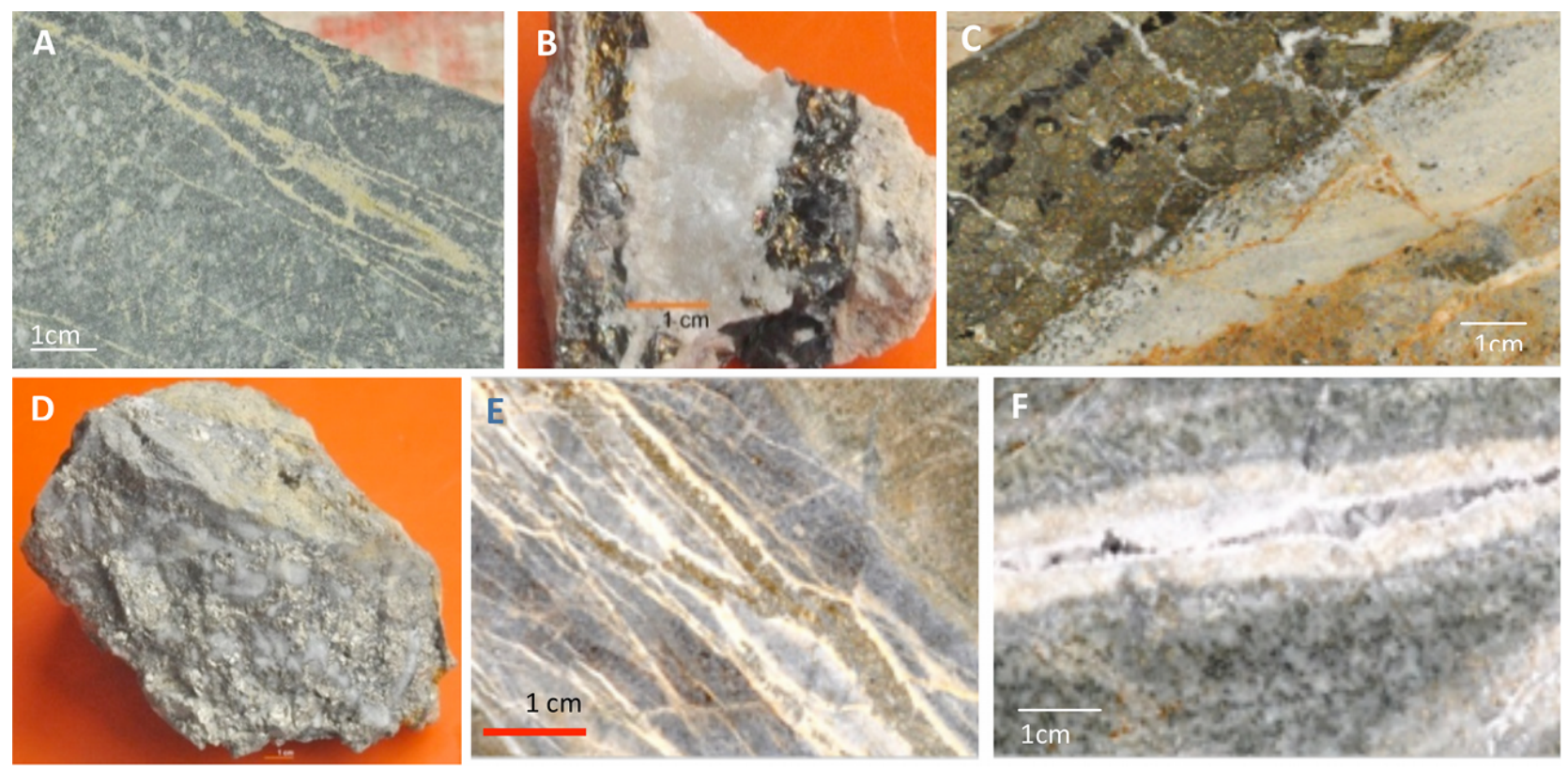

Figure 8: Many epithermal vein types at the Randu Kuning area: A) Epidote-quartz veinlets within chlorite-epidote-carbonate-quartz alteration (WDD 59-122.30); B) Chalcopyrite-sphalerite-quartpyrite vein and carbonate centre line in Kepil Hill; C) Pyrite-sphalerite-carbonate vein with sericite selvage (WDD54-156.80); D) Quartz-pyrite vein typical in Lancil Hill; E) Pyrite-chalcopyrite-silicacarbonate vein with sericite selvage (Location deep porphyry Randu Kuning (WDD 19-449.75); F) Carbonate-gypsum vein.

dissemination and open space infilling (Table 1).

There are at least two phreatomagmatic breccia stages at the area, firstly is related with porphyry environment and the second one associated to the epithermal processes. The characteristics between such two phreatomagmatic breccias type in the researched area is relatively similar, particularly in the composition, size and roundness of fragments, fragment matrix ratio, and mineralization styles, but different in the geometry of breccia body, matrix composition, texture and alteration type (Table 2. Figures 10-11). Geometry of breccia body of porphyry level phreatomagmatic breccia, mostly as irregular dyke, while in the epithermal level probably as pipe body. Magnetite, chlorite and chalcopyrite are common hydrothermal minerals which present as open space infilling matrix, otherwise in the epithermal level, pore space commonly were infilled by sphalerite, pyrite, epidote and carbonate. Breccia textures of epithermal enviroment more vary than those of porphyry level, consist of bedded, graded bedding, rebrecciated clasts and cut by many vein/veinlets. Corbett (2011) stated that the upper portion of phreatomagmatic breccia pipe of Jangglengan (WDD23) is intersects milled matrix breccia typical of other Pacific rim phreatomagmatic breccia pipes interpreted to have breached the surface, characterized by the bedded, locally graded bedding and possibility of accretionary lapilli components.

\section{Veins and hydrothermal breccias con- trol on $\mathrm{Cu}-\mathrm{Au}$ mineralizations}

Most of the mineralization at the Randu Kuning area are related to the veins/veinlets and hydrothermal breccias, and can be summarized as follows:

Barren quartz-magnetite veins: Some barren quartz veins are recognized in the deeper portion of some intrusions, and mostly associated with the present of magnetite but without sulphide ( $\mathrm{A}$ and $\mathrm{M}$ veins). It may due to by the 

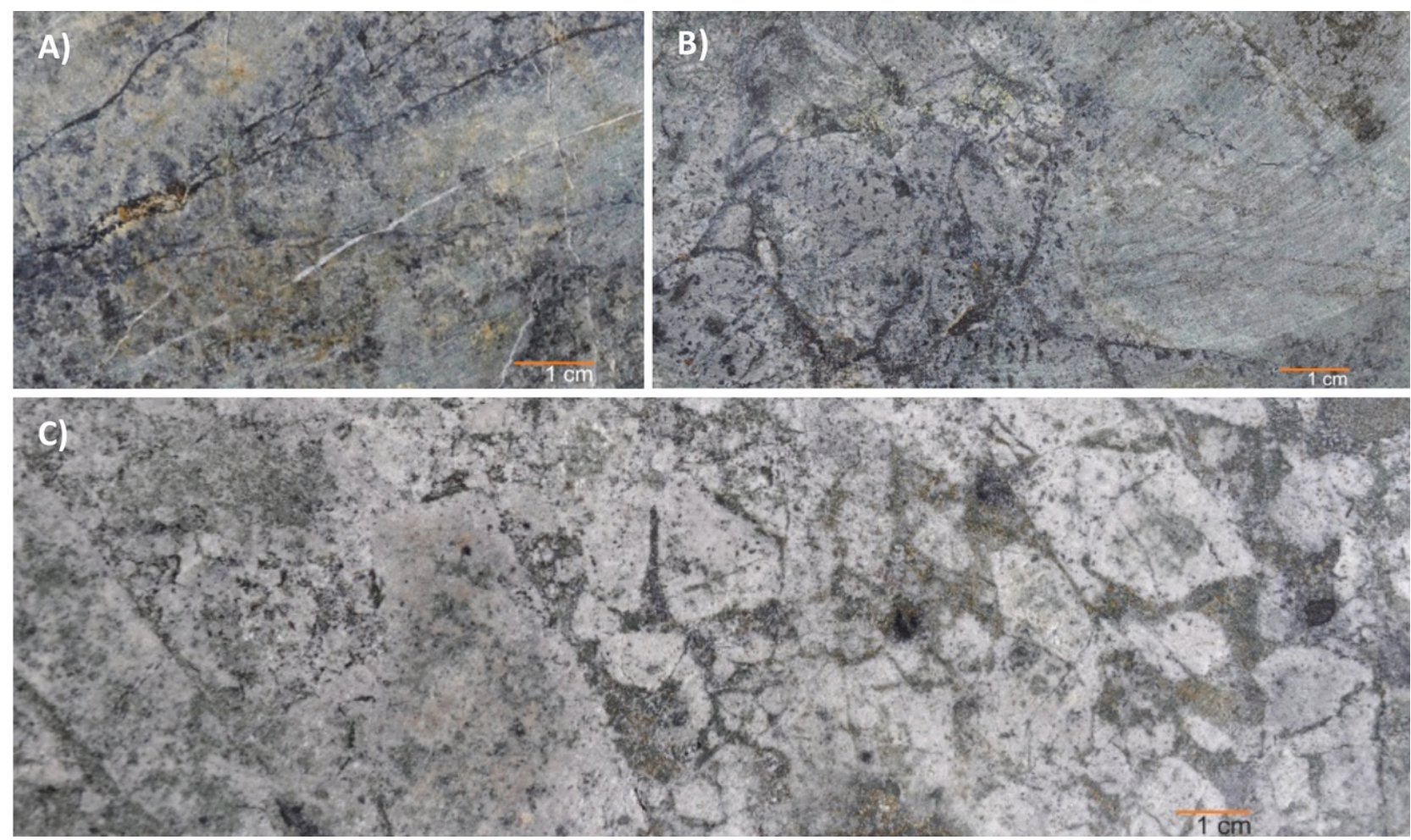

Figure 9: Magmatic hydrothermal stages: A) Hydrothermal fluids infilling rock fractures as magnetite-silicate veinlets (WDD2-49.80); B) magmatic hydothermal crackel breccia (WDD 0251.30); C) Magmatic hydrothermal breccia with magmetite infilling pore space between fragments as matrix (WDD 02-84.00).
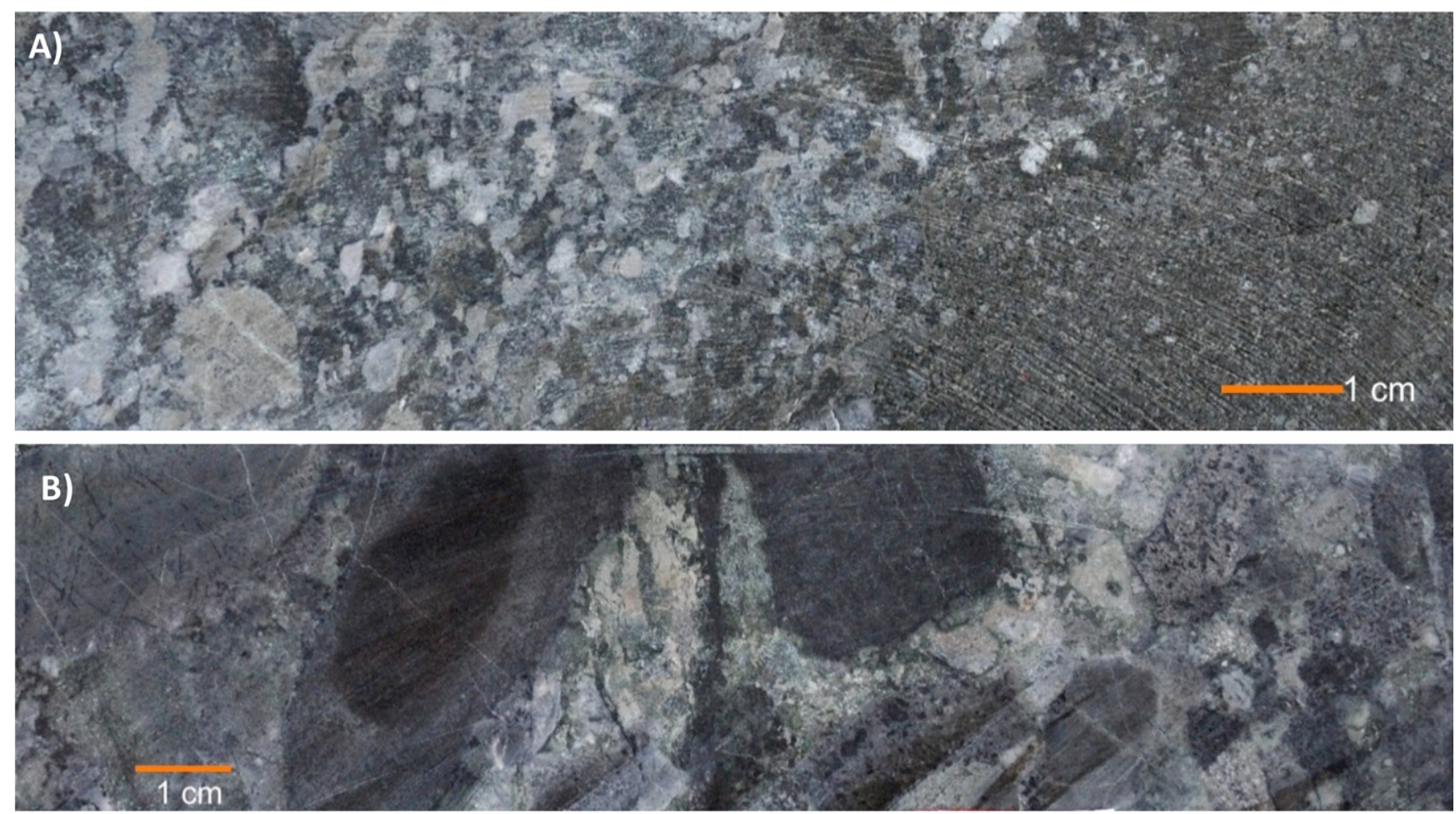

Figure 10: A) Contact hornblende-pyroxene diorite with Phreatomagmatic breccia (WDD48-391.70); B) Phreatomagmatic breccia (WDD 48-374.74). 

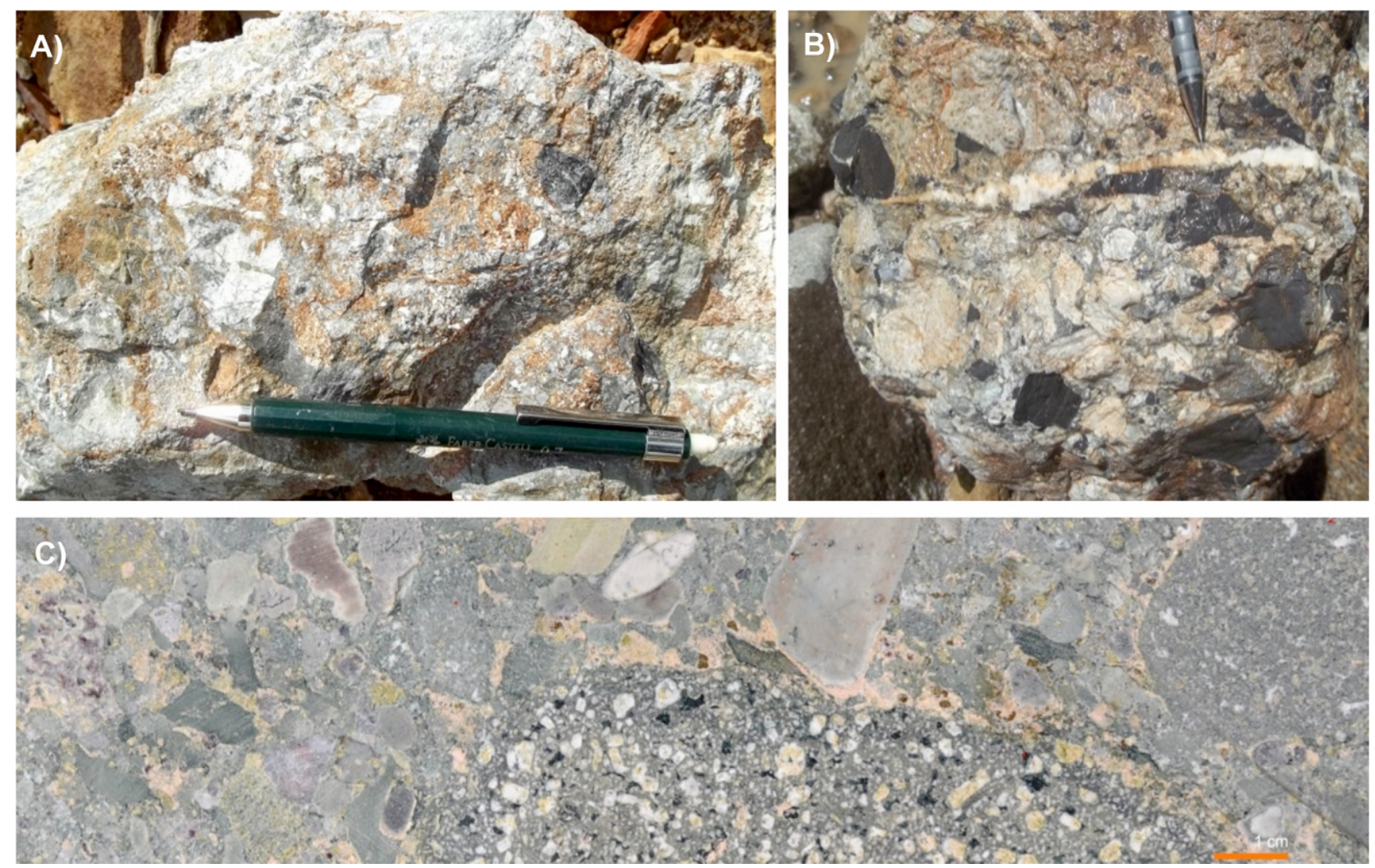

Figure 11: A) Preatomagmatic breccia. Fragments/clasts consist of juvenil, altered diorite. Location: Jangglengan prospect; B) Phreatomagmatic breccia with clast diorite, juvenil, quartzite, schist, cut by carbonate-sphalerite-pyrite-galena vein; C) Phreatomagmatic breccia with clast diorite and juvenil (WDD 34-124.50). 
high temperature, during the veins were developed. Based on the fluid inclusions analysis of $\mathrm{A}$ and $\mathrm{M}$ veins, the temperature of hydrothermal fluid is at $>600^{\circ} \mathrm{C}$, it was not condition for gold-copper precipitations.

Quartz-sulphides veins mineralization: In the upper portion and later stage or at the time of the ore fluids ascending, the quartz veins accompanied by minor sulphides and can develop $A B$ veins (formed by the filling at central termination within A veins by sulphides), $C$ veins (chalcopyrite-pyrite veins), and on the reactivated lamination parting of laminated M veins (Corbett, 2011; 2012). These quartzsulphides veins are commonly associated with the $\mathrm{Au}-\mathrm{Cu}$ mineralization. Stockwork $\mathrm{AB}$ vein cut by $\mathrm{C}$ style chalcopyrite vein in WDD8$1384 \mathrm{~m}$ comprising $1 \mathrm{~g} / \mathrm{t} \mathrm{Au} ; 2570 \mathrm{ppm} \mathrm{Cu}$ (Corbett, 2012).

D veins mineralization: This vein type comprise quartz, sulphides and carbonate with prominent silica-sericite \pm pyrite alteration salvages. $\mathrm{D}$ vein is distinguished to epithermal veins by width, banding/centre line as well as contact with the wall rocks. This vein is a latest vein in porphyry environment or may as a transition from porphyry to epithermal environment. D veins most common occurred within fault zones, overprinting of earlier barren quartz+magnetite veins, quartz-sulphides veins and disseminated sulphides mineralization. It may contain locally elevated $\mathrm{Au}$ to 5 $\mathrm{g} / \mathrm{t} \mathrm{Au}, 1.1 \mathrm{~g} / \mathrm{t} \mathrm{Ag}$ and $292 \mathrm{~g} / \mathrm{t} \mathrm{Cu}$ (in DDH WDD18-358.4m) with typically low Ag:Au ratios of 0.2 (Corbett, 2011; 2012).

Epithermal veins: The vein which associated with mineralization particularly is pyrite+sphalerite+chalcopyrite+quartz+carbonate vein. Many sulphides such as pyrite, chalcopyrite, sphalerite and lack of galena within open space hydrothermal breccia also have important role in gold-silver-zinc-lead mineralization, particularly in the epithermal environmment.
Hydrothermal breccias: Many hydrothermal breccia, both porphyry and epithermal environment, have contribution in $\mathrm{Cu}-\mathrm{Au}$ mineralization. Many of porphyry level-magmatic hydrothermal breccias matrix comprising dissemination of chalcopyrite-magnetite-pyrite. Brecciated pyrite-carbonate vein in Geblag (WDD 54 depth 167-169m) contains 0.63-2.229ppm $\mathrm{Au}, 28.1-31.4 \mathrm{ppm} \mathrm{Ag}$, 784-1150ppm As, 0,45$0.65 \% \mathrm{Cu}, 301-640 \mathrm{ppm} \mathrm{Pb}$ and $0.054-0.57 \%$ Zn. Hydrothermal breccia at the Jangglengan prospect has also an important role in $\mathrm{Au}-\mathrm{Zn}$-Ag mineralization. Drilling core samples of WDD 69 depth 70-76m comprising 0.31.08ppm Au, 1-1.4 ppm Ag, 33-195ppm Pb, 182-2010ppm Zn and 13-56ppm As.

\section{Conclusions}

Many types and stages of veins both porphyry and epithermal environment were recognized at the researched area, but not all vein types contributed in metas mineralization. The early quartz-magnetite veins (particularly $\mathrm{A}$ and $\mathrm{M}$ veins) generally not contain $\mathrm{Cu}-\mathrm{Au}$ or barren, while the later sulphide bearing veins mostly are rich of copper and gold (AB, C, $D$ and epithermal veins). Some $D$ style and or epithermal veins comprising sphaleritepyrite-carbonate and contain no chalcopyrite, magnetite and lesser bornite indicating low temperature environment formed at the deeper porphyry levels cross cut many high temperature early quartz-magnetite porphyry type veins ( $\mathrm{A}$ and $\mathrm{M}$ veins). The lower temperature veins may were developed by hydrothermal fluids of the cooling very fast of magma or different stage of magmatism. There are at least two type of hydrothermal breccia have recognized in the research area, i.e. magmatichydrothermal breccias and phreatomagmatic breccias, which were found at the Randu Kuning hill area, have taken place both in porphyry and epithermal environment. Many of porphyry level-magmatic hydrothermal breccias matrix comprising dissemination of chalcopyrite-magnetite-pyrite and contributed on $\mathrm{Cu}$-Au mineralization, while the epithermal 
hydrothermal breccia contributed to Au-Ag-Zn mineralization.

\section{Acknowledgements}

Our sincere thanks go to the management of PT. Alexis Perdana Mineral, which has given us permission to do this research in the Selogiri prospect area and its vicinity. Special thanks to Mas Sapto and his staff, Mbak Dina, and Rama Dani (Methun) for their facilities support and assistance during the fieldwork. We also would like to thank the Head and staff of the Institute of Mineralogy and Economic Geology (IML) of Aachen (RWTH) University, Germany and the Geological Engineering Department, Faculty of Engineering, Gadjah Mada University who gave me permission to access to the laboratories.

\section{References}

Baker, E.M., Kirwin, D.J., and Taylor, R.G. (1986) Hydrothermal Breccia Pipes, Contributions of the Economic Geology Research Unit, Geology Department James Cook University of North Queensland, 45p.

Bemmellen, van, R.W. (1949) The Geology of Indonesia, and Adjacent Archipelagoes, Vol. IA, Gov. Print. Office, Martinus Nijhoff, the Hague.

Carlile, J.C. dan Mitchell, A.H.G. (1994) Magmatic Arcs and Associated Gold and Copper Mineralisation in Indonesia, Journal of Geochemical Exploration, Elsevier Science, Amsterdam, 50: 92-142.

Corbett, G. (2008) Influence of Magmatic Arc Geothermal Systems on PorphyryEpithermal Au-Cu-Ag Exploration Models, Paper presented at the Terry Leach Symposium, Sydney, 17 October 2008. Australian Institute of Geoscientist Bulletin 48.

Corbett, G. (2011) Comments on The Exploration Potential of The Wonogiri Porphyry $\mathrm{Cu}-\mathrm{Au}$ Project, Central Java, Indonesia, Corbett Geological Services Pty. Ltd., Unpublished, 27p.

Corbett, G. (2012) Further Comments on The Wonogiri Porphyry $\mathrm{Cu}-\mathrm{Au}$ Project Central
Java, Indonesia, Corbett Geological Services Pty. Ltd., Unpublished, 37p.

Creasey, S.C. (1966) Hydrothermal Alteration, op.cit. p. 51-74.

Gustafson, L.B. dan Hunt, J.P. (1975) The Porphyry Copper Deposit at El Salvador, Chile, Economic Geology 70: 857-912.

Hamilton,W.B. (1979) Tectonics of the Indonesian Region. Professional Paper 1078, U.S. Geolology Survey, Washington, DC., 345 p.

Hartono, H.G. (2010) The Role of Paleovolcanism in The Tertiary Volcanic Rock Product Setting at Gajahmungkur Mt., Wonogiri, Central Java, Dissertation in UNPAD, Unpublished, 190p.

Hedenquist, J.W., Arribas, A.J., and Reynolds, T.J. (1998) Evolution of Intrusion-Centered Hydrothermal System: Far SoutheastLepanto Porphyry and Epithermal $\mathrm{Cu}-\mathrm{Au}$ deposits, Philipines, Economic Geology 93: 373-404.

Imai, A., Shinomiya, J., Soe, M.T., Setijadji, L.D., Watanabe, K., and Warmada, IW. (2007) Porphyry-Type Mineralization at Selogiri Area, Wonogiri Regency, Central Java, Indonesia, Resources Geology 57: 230-240.

Isnawan, D., Sukandarrumidi and Sudarno, I. (2002) Kontrol Struktur Geologi Terhadap Jebakan Tembaga Sebagai Arahan Eksploitasi di Daerah Ngerjo dan Sekitarnya Kecamatan Tirtomoyo, Kabupaten Wonogiri Propinsi Jawa Tengah, Gama Sains IV (2) Juli 2002, pp.149-157.

Katili, J. A., 1989. Evolution of the Southeast Asian arc complex, Geology Indonesia. Jakarta, 12: 113-143.

Kouzmanov, K., Moritz, R., von Quadt, A., Chiaradia, M., Peytcheva, I., Fontignie, D., Ramboz, C., and Bogdanov, K. (2009) Late Cretaceous Porphyry $\mathrm{Cu}$ and Epithermal $\mathrm{Cu}-$ $\mathrm{Au}$ Association in the Southern Panagyurishte District, Bulgaria: the Paired Vlaykov Vruh and Elshitsa Deposits, Mineralium Deposita 44: 611-646.

Lawless, J.V. and White, P.J. (1990) Ore-Related Breccia: A Revised Genetic Classification, with Particular Reference to Epithermal Deposits, 12th New Zealand Geothermal Workshop 1990. 
Maryono, A., Setijadji, L.D., Arif, J., Harrison, R., Soeriaatmadja, E. (2012) Gold, Silver and Copper Metallogeny of the Eastern Sunda Magmatic Arc Indonesia, Proceeding of Banda and Eastern Sunda Arcs 2012 MGEI Annual Convention, 26-27 November 2012, Malang, East Java, Indonesia, pp. 23-38.

Muntean, J.L. and Einaudi, M.T. (2001) Porphyry-Epithermal Transition: Maricunga Belt, Northern Chile, Economic Geology 96: 743-772.

Muthi, A., Basten, I.G., Suasta, I.G.M., and Litaay, N.E.W. (2012) Characteristic of Alteration and Mineralization at Randu KuningWonogiri Project, Proceeding of Banda and Eastern Sunda Arcs 2012 MGEI Annual Convention, 26-27 November 2012, Malang, East Java, Indonesia, pp. 117-132.

Seedorff, E., Dilles, J.H., Proffett, Jr., J.M., Einaudi, M.T., Zurcher, L., Stavast, W..J.A, Jonhson, D.A., and Barton, M. (2005) Porphyry Deposit: Characteristics and Origin of Hypgene Features, Economic Geology 65: 251-298.

Setijadji, L.D., Kajino, S., Imai, A., and Watanabe, K. (2006) Cenozoic Island Arc Magmatism in Java Island (Sunda Arc, Indonesia): Clues on Relationships between Geodynamics of Volcanic Centers and Ore Mineralization, Resources Geology 56: 267-292.

Setijadji, L.D., and Maryono, A. (2012) Geology and Arc Magmatism of the Eastern Sunda Arc, Indonesia, Proceeding of Banda and Eastern Sunda Arcs 2012 MGEI Annual Convention, 26-27 November 2012, Malang, East Java, Indonesia, p.1-22.

Sillitoe, R.H. (1985) Ore-Related Breccias in Volcanoplutonic Arcs, Economic Geology 80: 1467-1514.

Sillitoe, R.H. (2010) Porphyry Copper System, Economic Geology 105: 3-41.

Smyth, H.L., Hall, R. and Nichols, G. (2008) Cenozoic Volcanic Arc History of East Java
Indonesia: The Stratigraphic Record of Eruption on An Active Continental Margin, The Geological Society of America Special Paper No. 436, p. 199-221.

Suasta, I.G.M and Sinugroho, I.A. (2011) Occurrence of Zoned Epithermal to Porphyry Type $\mathrm{Cu}-\mathrm{Au}$ Mineralization at Wonogiri, Central Java, Proceeding of The $36^{\text {th }}$ HAGI and $40^{\text {th }}$ IAGI Annual Convention.

Suprapto (1998) Model Endapan Emas Epitermal Daerah Nglenggong, Kecamatan selogiri, Kabupaten Wonogiri, Jawa Tengah. Tesis Magister, Program Studi Rekayasa Pertambangan, Fakultas Pasca Sarjana, Institut Teknologi Bandung, $47 \mathrm{p}$.

Surono, Toha, B., and Sudarno, I. (1992) Geological map of the Surakarta-Giritontro Quadrangles, Java, Geological Research and Development Centre, Bandung.

Sutarto, Idrus, A., Putranto, S., Harijoko, A., Setijadji, L.D., Meyer, F.M., and Danny, R. (2013) Veining Paragenetic Sequence of The Randu Kuning Porphyry $\mathrm{Cu}-\mathrm{Au}$ Deposit at Selogiri Area, Central Java. Extended Abstract: CD Proceeding of The $38^{\text {th }}$ HAGI and $42^{\text {nd }}$ IAGI Annual Convention and Exibition Medan, 28-31 October 2013.

Sutarto, Idrus, A., Meyer, F.M., Harijoko, A., Setijadji, L.D., and Danny, R. (2013) The Dioritic Alteraation Model of The Randu Kuning Porphyry Cu-Au, Selogiri Area, Central Java. Proceedings International Conference on Georesources and Geological Engineering, December 11-12, 2013 Yogyakarta, ISBN 978-602-14066-5-6. p.122-132.

Prihatmoko, S., Digdowirogo, S., and Kusumanto, D. (2002) Potensi Cebakan Mineral di Jawa Tengah dan Daerah Istimewa Yogyakarta. Prosiding Seminar Geologi Jawa Tengah dan Daerah Istimewa Yogyakarta, Ikatan Ahli Geologi Indonesia Pengda Yogyakarta, p. 87-108. 